\title{
Dyadobacter ginsengisoli sp. nov., isolated from soil of a ginseng field
}

Correspondence
Wan-Taek Im
wandra@kaist.ac.kr

\author{
Qing-Mei Liu, ${ }^{1}$ Wan-Taek Im, ${ }^{1}$ Myungjin Lee, ${ }^{1,2}$ Deok-Chun Yang ${ }^{3}$ \\ and Sung-Taik Lee ${ }^{1}$ \\ ${ }^{1}$ Department of Biological Sciences, Korea Advanced Institute of Science and Technology, \\ 373-1, Guseong-dong, Yuseong-gu, Daejeon 305-701, Republic of Korea \\ ${ }^{2}$ NeoPharm Co., Ltd, BVC-307, KRIBB, 52 Oeun-dong, Yuseong-gu, Daejeon 305-333, \\ Republic of Korea \\ ${ }^{3}$ Department of Oriental Medicinal Material and Processing College of Life Science, \\ Kyung Hee University, 1 Seocheon, Kihung Yongin, Kyunggi 449-701, Republic of Korea
}

A Gram-negative, aerobic, non-motile, non-spore-forming and rod-shaped bacterium, strain Gsoil $043^{\top}$, was isolated from soil from a ginseng field in Pocheon province, South Korea. The novel isolate was characterized in order to determine its taxonomic position. On the basis of 16S rRNA gene sequence similarity, strain Gsoil $043^{\top}$ was shown to belong to the family 'Flexibacteraceae' and was related to Dyadobacter fermentans (96.7\%), Dyadobacter crusticola (96.3\%) and Dyadobacter hamtensis (95.8\%). The 16S rRNA gene sequence similarity of the novel strain to other recognized species within the family 'Flexibacteraceae' was less than $87 \cdot 0 \%$. The $G+C$ content of genomic DNA was 48 mol\%. Phenotypic and chemotaxonomic data (major menaquinone, MK-7; major fatty acids, $\mathrm{C}_{16: 1} \omega 7 \mathrm{c}$, iso- $\mathrm{C}_{15: 0}$ and $\mathrm{C}_{16: 0}$ ) supported the affiliation of strain Gsoil $043^{\top}$ to the genus Dyadobacter. The results of physiological and biochemical tests enabled strain Gsoil $043^{\top}$ to be differentiated genotypically and phenotypically from the three Dyadobacter species with validly published names. The novel isolate therefore represents a novel species for which the name Dyadobacter ginsengisoli sp. nov. is proposed, with the type strain Gsoil $043^{\top}\left(=\right.$ KCTC $12589^{\top}=$ LMG $\left.23409^{\top}\right)$.
During a study of the culturable aerobic bacterial community in soil from a ginseng field in Pocheon province, South Korea, a large number of novel bacterial strains was isolated (Im et al., 2005). One of these isolates, strain Gsoil $043^{\mathrm{T}}$, was found to be a member of the genus Dyadobacter (family 'Flexibacteraceae') and was subjected to a taxonomic investigation.

The genus Dyadobacter was described by Chelius \& Triplett (2000) to accommodate Gram-negative, rod-shaped cells that are straight to curved, occur in pairs in young cultures and form chains of coccoid cells in old cultures and produce a flexirubin-like pigment (Reddy \& Garcia-Pichel, 2005). At present, the genus comprises three species: Dyadobacter fermentans (Chelius \& Triplett, 2000), Dyadobacter crusticola (Reddy \& Garcia-Pichel, 2005) and Dyadobacter hamtensis (Chaturvedi et al., 2005).

For the present study, we conducted phylogenetic (16S rRNA gene), phenotypic, genotypic and chemotaxonomic analyses to determine the precise taxonomic position of

The GenBank/EMBL/DDBJ accession number for the 16S rRNA gene sequence of strain Gsoil $043^{\top}$ is AB245369. strain Gsoil $043^{\mathrm{T}}$. On the basis of the results obtained, we propose that strain Gsoil $043^{\mathrm{T}}$ should be placed in the genus Dyadobacter as the type strain of novel species.

Strain Gsoil $043^{\mathrm{T}}$ was originally isolated from soil from a ginseng field in Pocheon province, South Korea. The soil sample was thoroughly suspended with $50 \mathrm{mM}$ phosphate buffer ( $\mathrm{pH} \mathrm{7 \cdot 0)}$ and the suspension was spread on one fifthstrength modified R2A $(0 \cdot 25 \mathrm{~g}$ tryptone, $0.25 \mathrm{~g}$ peptone, $0.25 \mathrm{~g}$ yeast extract, $0.125 \mathrm{~g}$ malt extract, $0.125 \mathrm{~g}$ beef extract, $0.25 \mathrm{~g}$ Casamino acids, $0.25 \mathrm{~g}$ soytone, $0.5 \mathrm{~g}$ glucose, $0.3 \mathrm{~g}$ soluble starch, $0.2 \mathrm{~g}$ xylan, $0.3 \mathrm{~g}$ sodium pyruvate, $0 \cdot 3 \mathrm{~g} \mathrm{~K}_{2} \mathrm{HPO}_{4}, 0 \cdot 05 \mathrm{~g} \mathrm{MgSO}_{4}, 0.05 \mathrm{~g} \mathrm{CaCl}_{2}$ and $15 \mathrm{~g}$ agar $1 \mathrm{l}^{-1}$ ) agar plates after serial dilution with $50 \mathrm{mM}$ phosphate buffer $(\mathrm{pH} 7 \cdot 0)$. The plates were incubated at $30{ }^{\circ} \mathrm{C}$ for 1 month. Single colonies on the plates were purified by transferring them onto new plates and these were incubated again on modified R2A or half-strength modified R2A. Purified colonies were tentatively identified by partial sequences of the 16S rRNA gene (Im et al., 2005). Strain Gsoil $043^{\mathrm{T}}$ was one of the predominant isolates on modified R2A agar plates in aerobic conditions. Strain Gsoil $043^{\mathrm{T}}$ was routinely cultured on $\mathrm{R} 2 \mathrm{~A}$ agar at $30{ }^{\circ} \mathrm{C}$ and maintained as a glycerol suspension $(20 \%, \mathrm{w} / \mathrm{v})$ at $-70^{\circ} \mathrm{C}$. 
Gram-reaction testing was performed by the non-staining method as described by Buck (1982). Cell morphology was observed at $\times 1000$ magnification with a light microscope (Nikon) using cells grown for 3 days at $30^{\circ} \mathrm{C}$ on R2A agar. Catalase activity was determined by bubble production in $3 \%(\mathrm{v} / \mathrm{v}) \mathrm{H}_{2} \mathrm{O}_{2}$ and oxidase activity was determined using $1 \%(\mathrm{w} / \mathrm{v})$ tetramethyl $p$-phenylenediamine. For single carbon source assimilation studies, a defined liquid medium containing basal salt media was used composed of $\left(\mathrm{g} \mathrm{l}^{-1}\right)$; $1.8 \mathrm{~g} \mathrm{~K}_{2} \mathrm{HPO}_{4}, 1.08 \mathrm{~g} \mathrm{KH}_{2} \mathrm{PO}_{4}, 0.5 \mathrm{~g} \mathrm{NaNO}_{3}, 0.5 \mathrm{~g} \mathrm{NH}_{4} \mathrm{Cl}$, $0.1 \mathrm{~g} \mathrm{KCl}, 0.1 \mathrm{~g} \mathrm{MgSO}_{4}$ and $0.05 \mathrm{~g} \mathrm{CaCl}_{2}$. A vitamin solution (Widdel \& Bak, 1992), trace element solution SL10 (Widdel et al., 1983) and selenite/tungstate solution (Tschech \& Pfennig, 1984) were added to this medium and the $\mathrm{pH}$ was adjusted to $6 \cdot 8$. This liquid medium was aliquoted into 96-well trays and filter-sterilized carbon sources were added to each well (individually at $0 \cdot 1 \% \mathrm{w} / \mathrm{v}$ ). Growth was visually examined on 96-well plates incubated at $30^{\circ} \mathrm{C}$ for up to 7 days. A negative control well, containing no carbon sources, was included. A positive control culture was grown in a well containing R2A broth.

Fermentative and oxidative acid production from carbohydrates was tested by growth in $\mathrm{O}-\mathrm{F}$ basal medium with bromothymol blue (Atlas, 1993) supplemented with $1 \%$ carbohydrate [soft agar stabs with (fermentative) and without (oxidative) sterile mineral oil overlay]. The O-F medium tubes were incubated at $30^{\circ} \mathrm{C}$ for 5 days. Some physiological characteristics were determined with API 20E galleries according to the manufacturer's instructions (bioMérieux). Anaerobic growth was tested in serum bottles by adding $1 \mathrm{~g}$ thioglycolate $\mathrm{l}^{-1}$ to R2A broth and substituting the upper air layer with nitrogen gas. The anaerobic nitrate reduction test to determine the final electron acceptor was performed in serum bottles by adding $1 \mathrm{~g}$ thioglycolate $\mathrm{l}^{-1}$ and $10 \mathrm{mM}$ $\mathrm{KNO}_{3}$ to R2A broth under nitrogen gas. Aerobic nitrate reduction was later confirmed by inoculation into $12 \mathrm{ml}$ R2A broth supplemented with $10 \mathrm{mM} \mathrm{KNO}_{3}$ in three $25 \mathrm{ml}$ serum bottles. The reduction of nitrate was monitored by an ion chromatograph (model 790 personal IC; Metrohm) equipped with a conductivity detector and an anion exchange column (Metrosep Anion Supp 4; Metrohm). Tests for the degradation of DNA (DNase agar Scharlau by flooding plates with $1 \mathrm{M} \mathrm{HCl}$ ), casein, chitin, starch (Atlas, 1993), lipid (Kouker \& Jaeger, 1987), xylan and cellulose (Ten et al., 2004) were performed and evaluated after 5 days. Growth at different temperatures $(4,15,25,30,37$ and $42^{\circ} \mathrm{C}$ ) and various $\mathrm{pH}$ values ( $\mathrm{pH} 5 \cdot 0-10 \cdot 0$ at intervals of $0.5 \mathrm{pH}$ units) was assessed after 5 days incubation. Salt tolerance was tested on R2A agar supplemented with 1-10\% $(\mathrm{w} / \mathrm{v}) \mathrm{NaCl}$ after 5 days incubation. Growth on nutrient agar, trypticase soy agar (TSA) and MacConkey agar at $30^{\circ} \mathrm{C}$ was also evaluated. Pigment was extracted according to a previously described method (Weeks, 1981) and a spectrum was obtained using a UV-visible spectrophotometer (Beckman). Additionally, the presence of flexirubin-type pigments was tested spectrophotometrically as described previously (Güde, 1980) using $20 \% \mathrm{KOH}$.
Extraction of genomic DNA was performed with a commercial genomic DNA extraction kit (Core Biosystem) and PCR-mediated amplification of the 16S rRNA gene and sequencing of the purified PCR product were carried out according to Kim et al. (2005). Full sequences of the $16 \mathrm{~S}$ rRNA gene were compiled using SeqMan software (DNASTAR). The 16S rRNA gene sequences of related taxa were obtained from GenBank. Multiple alignments were performed with CLUSTAL_X (Thompson et al., 1997). Gaps were edited using BIOEDIT (Hall, 1999). Evolutionary distances were calculated using the Kimura two-parameter model (Kimura, 1983). Phylogenetic trees were constructed using the neighbour-joining (Saitou \& Nei, 1987) and maximum-parsimony (Fitch, 1971) methods using the MEGA3 program (Kumar et al., 2004) with bootstrap values based on 1000 replications (Felsenstein, 1985).

For the measurement of the $\mathrm{G}+\mathrm{C}$ content of chromosomal DNA, genomic DNA of the novel strain was extracted and purified as described by Moore \& Dowhan (1995) and was enzymically degraded into nucleosides. DNA G + C content was determined as described by Mesbah et al. (1989) using a reverse-phase HPLC. Isoprenoid quinones were extracted with chloroform/methanol $(2: 1, \mathrm{v} / \mathrm{v})$, evaporated under vacuum conditions and reextracted in n-hexane/ water $(1: 1, \mathrm{v} / \mathrm{v})$. The crude $\mathrm{n}$-hexane-quinone solution was purified using Sep-Pak Vac cartridges silica (Waters) and subsequently analysed by HPLC as previously described (Hiraishi et al., 1996). Cellular fatty acid profiles were determined for strains grown on TSA (Difco) for 2 days. Cellular fatty acids were saponified, methylated and extracted according to the protocol of the Sherlock Microbial Identification System (MIDI). The fatty acids analysed by GC (6890; Hewlett Packard) were identified by the Microbial Identification software package (Sasser, 1990).

Strain Gsoil $043^{\mathrm{T}}$ was aerobic, Gram-negative, non-motile and rod-shaped. Colonies grown on R2A agar plates for 5 days were smooth, circular, transparent, yellowish and 3-7 $\mathrm{mm}$ in diameter. The novel strain grew well on nutrient agar and TSA. On R2A agar medium, strain Gsoil $043^{\mathrm{T}}$ was able to grow at $4-30{ }^{\circ} \mathrm{C}$, but not $37^{\circ} \mathrm{C}$. A flexirubin-like yellow-coloured pigment was produced. The pigment exhibited peaks at 412 and $448 \mathrm{~nm}$ when extracted in ethanol. The addition of alkali $(20 \% \mathrm{KOH})$ changed the colour of the pigment to orange and also broadened the peak, thus confirming that it is a flexirubin-type pigment (Weeks, 1981). Other physiological characteristics of strain Gsoil $043^{\mathrm{T}}$ are summarized in the species description and comparisons of selective characteristics with closely related type strains are shown in Table 1.

The 16S rRNA gene sequence of strain Gsoil $043^{\mathrm{T}}$ determined in this study was a continuous stretch of $1451 \mathrm{bp}$ (base position 20-1505 with respect to the Escherichia coli numbering system). Sequence similarity calculations after a neighbour-joining analysis indicated that the closest relatives of strain Gsoil $043^{\mathrm{T}}$ were D. fermentans NS $114^{\mathrm{T}}$ ( $96 \cdot 7 \% 16 \mathrm{~S}$ rRNA gene sequence similarity), D. crusticola 
Table 1. Physiological characteristics of Dyadobacter ginsengisoli sp. nov. Gsoil $043^{\top}$ and related species of the genus Dyadobacter

Strains: 1, D. ginsengisoli Gsoil $043^{\mathrm{T}}$ sp. nov. (data from this study); 2, D. hamtensis HHS $11^{\mathrm{T}} ; 3, D$. crusticola $\mathrm{C} 183-8^{\mathrm{T}} ; 4$, D. fermentans NS $114^{\mathrm{T}}$. Data for strains $2-4$ are from Chaturvedi et al. (2005). All strains are Gram-negative, non-motile, rod-shaped, test positive for catalase and oxidase activities and can tolerate $1 \% \mathrm{NaCl}$. All strains test positive for the utilization of D-glucose, D-cellobiose, sucrose, Dtrehalose, D-raffinose, D-lactose and inulin as carbon sources and are resistant to penicillin (10 $\mu \mathrm{g}$ per disc). All strains are negative in tests for urease, gelatinase, starch hydrolysis, citrate utilization, $\mathrm{H}_{2} \mathrm{~S}$ production, indole production and arginine dihydrolase activity. Strains 1, 3 and 4 do not utilize alanine, asparagine, aspartic acid, cysteine, glutamic acid, histidine, isoleucine, leucine, phenylalanine, proline, serine, threonine, tyrosine and valine, whereas strain 2 is able to utilize all of these amino acids. + , Positive; -, negative; V, variable; W, weak reaction; R, resistant; $S$, sensitive; NA, data not available.

\begin{tabular}{|c|c|c|c|c|}
\hline Characteristic & 1 & 2 & 3 & 4 \\
\hline Colony size $(\mathrm{mm})$ & $3-7$ & $2-3$ & NA & $2-3$ \\
\hline Colony colour & Yellow & Light yellow & Yellow & Orange \\
\hline Cell shape & Rods & Long rods & Rods & Rods \\
\hline Growth at $5{ }^{\circ} \mathrm{C}$ & + & - & + & - \\
\hline Growth at $37^{\circ} \mathrm{C}$ & - & + & - & + \\
\hline Maximum growth temperature $\left({ }^{\circ} \mathrm{C}\right)$ & 30 & 37 & 25 & 37 \\
\hline $\mathrm{pH}$ range & $5 \cdot 5-8 \cdot 5$ & $6-8$ & $6-8$ & $6-8$ \\
\hline Lipase activity & - & - & + & - \\
\hline Aesculin hydrolysis & - & - & + & + \\
\hline Fermentative metabolism & - & + & - & + \\
\hline Nitrate reduction (aerobic) & + & - & - & - \\
\hline DNA G + C content $(\mathrm{mol} \%)$ & 48 & 49 & 48 & 48 \\
\hline \multicolumn{5}{|l|}{ Acid production from } \\
\hline D-Arabinose & - & + & - & + \\
\hline D-Glucose & - & + & - & + \\
\hline Sucrose & - & - & - & + \\
\hline \multicolumn{5}{|l|}{ Utilization as a sole carbon source } \\
\hline Acetate & - & + & - & + \\
\hline D-Adonitol & + & + & - & - \\
\hline D-Arabinose & - & + & - & + \\
\hline L-Arabinose & + & + & - & + \\
\hline Cellulose & - & + & - & + \\
\hline Citrate & - & + & - & - \\
\hline Dextran & - & + & - & - \\
\hline Dulcitol & - & - & + & $\mathrm{W}$ \\
\hline D-Fructose & + & - & - & + \\
\hline Fumaric acid & - & + & - & + \\
\hline D-Galactose & + & + & - & + \\
\hline Glycerol & - & + & - & $\mathrm{W}$ \\
\hline Inositol & - & - & + & + \\
\hline Lactate & - & + & + & - \\
\hline Malonate & - & + & - & + \\
\hline D-Mannitol & - & - & $\mathrm{V}$ & + \\
\hline D-Mannose & + & - & - & + \\
\hline D-Ribose & - & - & + & - \\
\hline D-Sorbitol & - & - & + & $\mathrm{W}$ \\
\hline L-Sorbose & - & + & - & + \\
\hline Tartaric acid & - & + & - & + \\
\hline D-Xylose & + & - & + & + \\
\hline \multicolumn{5}{|l|}{ Amino acids: } \\
\hline Arginine & - & + & - & + \\
\hline Glutamine & - & + & - & + \\
\hline Glycine & - & + & - & + \\
\hline
\end{tabular}


Table 1. cont.

\begin{tabular}{|lllll|}
\hline Characteristic & $\mathbf{1}$ & $\mathbf{2}$ & $\mathbf{3}$ & $\mathbf{4}$ \\
\hline Lysine & - & + & - & + \\
Methionine & - & + & - & + \\
Tryptophan & - & + & - & + \\
Effect of antibiotics ( $\mu$ g per disc) & & & & \\
Chloramphenicol (30) & $\mathrm{R}$ & $\mathrm{S}$ & $\mathrm{R}$ & $\mathrm{R}$ \\
Rifampicin (25) & $\mathrm{R}$ & $\mathrm{S}$ & $\mathrm{S}$ & $\mathrm{R}$ \\
Streptomycin (25) & $\mathrm{R}$ & $\mathrm{S}$ & $\mathrm{R}$ & $\mathrm{R}$ \\
Tetracycline (30) & $\mathrm{R}$ & $\mathrm{S}$ & $\mathrm{S}$ \\
\hline
\end{tabular}

C183-8 $8^{\mathrm{T}}(96 \cdot 3 \%)$ and D. hamtensis HHS $11^{\mathrm{T}}(95 \cdot 8 \%)$. Lower sequence similarities $(<87 \cdot 0 \%)$ were found with all other recognized species of the family 'Flexibacteraceae'. This relationship between strain Gsoil $043^{\mathrm{T}}$ and other members of the genus Dyadobacter was also evident in the phylogenetic tree (Fig. 1). Strain Gsoil $043^{\mathrm{T}}$ and the three species of the genus Dyadobacter mentioned above formed a monophyletic clade with a high bootstrap value $(100 \%)$ which was supported by both tree-making methods employed in this study.

DNA-DNA hybridization between strain Gsoil $043^{\mathrm{T}}$ and its nearest phylogenetic neighbours was not attempted since strains differing by $>3 \cdot 0 \%$ at the $16 \mathrm{~S}$ rRNA gene sequence level are unlikely to exhibit $>70 \%$ relatedness at the whole genome level (Stackebrandt \& Goebel, 1994).

The $\mathrm{G}+\mathrm{C}$ content of the genomic DNA of strain Gsoil $043^{\mathrm{T}}$ was $48 \mathrm{~mol} \%$. MK-7 was the predominant menaquinone. The fatty acid profile of strain Gsoil $043^{\mathrm{T}}$ (Table 2) comprised mainly $\mathrm{C}_{16: 1} \omega 7 c(44 \cdot 6 \%)$, iso- $\mathrm{C}_{15: 0}(20 \cdot 3 \%)$ and $\mathrm{C}_{16: 0}(11 \cdot 0 \%)$. Significant differences in fatty acid profiles were found between strain Gsoil $043^{\mathrm{T}}$ and the other species of the genus Dyadobacter. D. hamtensis and D. fermentans contained significantly higher amounts of iso- $\mathrm{C}_{17: 0} 3-\mathrm{OH}$, whereas D. crusticola and strain Gsoil $043^{\mathrm{T}}$ contained significantly higher amounts of $\mathrm{C}_{16: 1} \omega 7 c$. However, strain Gsoil $043^{\mathrm{T}}$ contained significantly lower amounts of $\mathrm{C}_{16: 1} \omega 5 c$.
The species of the genus Dyadobacter could be differentiated from one another by the fatty acid profiles.

On the basis of the data and observations described above, strain Gsoil $043^{\mathrm{T}}$ should be assigned to the genus Dyadobacter as the type strain of a novel species, for which the name Dyadobacter ginsengisoli sp. nov. is proposed.

\section{Description of Dyadobacter ginsengisoli sp. nov.}

Dyadobacter ginsengisoli (gin.sen.gi.so'li. N.L. n. ginsengum ginseng; L. n. solum soil; N.L. gen. n. ginsengisoli of the soil of a ginseng field, the source of the type strain).

Cells are Gram-negative, aerobic, non-motile and rodshaped, $0 \cdot 6-0 \cdot 8 \mu \mathrm{m}$ in diameter and $3 \cdot 0-6 \cdot 0 \mu \mathrm{m}$ in length after 2 days culture on R2A agar. Colonies grown on R2A agar for 2 days are smooth, circular, transparent and yellowish. Grows well at $4-30{ }^{\circ} \mathrm{C}$ and at $\mathrm{pH} 5 \cdot 5-8 \cdot 5$, but does not grow at $37^{\circ} \mathrm{C}$. Growth occurs in the absence of $\mathrm{NaCl}$ and in the presence of $1.0 \%(\mathrm{w} / \mathrm{v}) \mathrm{NaCl}$, but not with $2 \%(\mathrm{w} / \mathrm{v})$ $\mathrm{NaCl}$. Nitrate is reduced in aerobic conditions. Anaerobic growth does not occur. Does not degrade DNA, chitin or xylan. Substrate utilization, enzyme production, acid production and other physiological characteristics are given in Table 1. In addition, is able to utilize L-rhamnose, D-lyxose, $N$-acetylglucosamine, salicin, D-lactose, D-maltose,

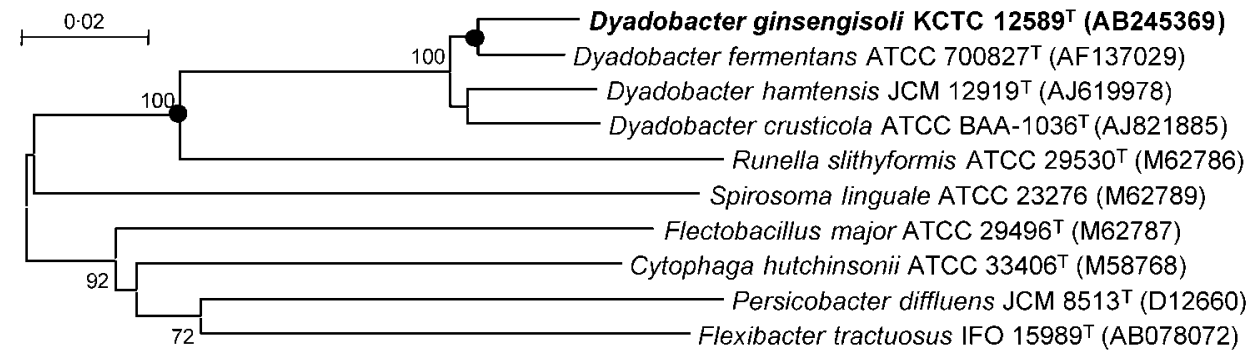

Fig. 1. Neighbour-joining phylogenetic tree constructed from a comparative analysis of $16 \mathrm{~S}$ rRNA gene sequences showing the relationships of Dyadobacter ginsengisoli sp. nov. Gsoil $043^{\top}$ with other related species. Filled circles at nodes indicate generic branches that were also recovered using maximum-parsimony algorithms. Bootstrap values (expressed as a percentage of 1000 replications) $>70 \%$ are shown at the branch points. Bar, 0.02 substitutions per nucleotide position. 
Table 2. Cellular fatty acid profiles of Dyadobacter ginsengisoli sp. nov. Gsoil $043^{\top}$ and related species of the genus Dyadobacter

Strains: 1, D. ginsengisoli Gsoil $043^{\mathrm{T}} \mathrm{sp}$. nov. (TSA at $30^{\circ} \mathrm{C}$, data from this study); 2, D. hamtensis HHS $11^{\mathrm{T}}$ (R2A medium at $25^{\circ} \mathrm{C}$ ); 3, D. crusticola $\mathrm{C} 183-8^{\mathrm{T}}$ (TSA at $25^{\circ} \mathrm{C}$ ); 4, D. fermentans NS $114^{\mathrm{T}}$ (R2A medium at $25^{\circ} \mathrm{C}$ ). Data for strains $2-4$ were taken from Chaturvedi et al. (2005). Major fatty acids are shown in bold type.

\begin{tabular}{|c|c|c|c|c|}
\hline Fatty acids & 1 & 2 & 3 & 4 \\
\hline $\mathrm{C}_{14: 0}$ & - & $1 \cdot 2$ & $1 \cdot 4$ & - \\
\hline iso- $\mathrm{C}_{15: 1}$ & - & $3 \cdot 7$ & $4 \cdot 5$ & - \\
\hline iso- $\mathrm{C}_{15: 0}$ & $20 \cdot 3$ & $24 \cdot 7$ & $13 \cdot 4$ & $22 \cdot 9$ \\
\hline $\mathrm{C}_{16: 1} \omega 5 c$ & $7 \cdot 9$ & $19 \cdot 8$ & $21 \cdot 4$ & $14 \cdot 3$ \\
\hline $\mathrm{C}_{16: 1} \omega 7 c$ & $44 \cdot 6$ & $14 \cdot 8$ & $41 \cdot 2$ & $28 \cdot 6$ \\
\hline $\mathrm{C}_{16: 0}$ & $11 \cdot 0$ & $8 \cdot 6$ & $12 \cdot 4$ & $5 \cdot 7$ \\
\hline iso- $\mathrm{C}_{15: 0} 3-\mathrm{OH}$ & $3 \cdot 9$ & - & $2 \cdot 4$ & $2 \cdot 9$ \\
\hline Unknown & $0 \cdot 8$ & - & $0 \cdot 3$ & - \\
\hline $\mathrm{C}_{16: 0} 3-\mathrm{OH}$ & $2 \cdot 3$ & $2 \cdot 5$ & $2 \cdot 2$ & $2 \cdot 9$ \\
\hline $\mathrm{C}_{18: 0}$ & - & - & $0 \cdot 2$ & - \\
\hline $\mathrm{C}_{18: 1}$ & - & $2 \cdot 5$ & $0 \cdot 8$ & - \\
\hline iso- $\mathrm{C}_{17: 0} 3-\mathrm{OH}$ & $7 \cdot 6$ & $22 \cdot 2$ & $2 \cdot 9$ & $22 \cdot 9$ \\
\hline
\end{tabular}

D-melibiose and inulin as sole carbon sources. Does not utilize D-fucose, ethanol, L-xylose, pyruvic acid, formic acid, propionate, 3-hydroxybutyrate, valerate, caprate, maleic acid, phenylacetate, benzoic acid, 3-hydroxybenzoate, 4-hydroxybenzoate, malate, succinic acid, glutaric acid, itaconate, adipate, suberate, oxalic acid, gluconate, xylitol, amygdalin, methanol or glycogen as sole carbon sources. Resistant to ( $\mu$ g per disc) tetracycline (100), ampicillin (100), kanamycin (100), rifampicin (100), chloramphenicol (100), carbenicillin (100), hygromycin (100) and streptomycin (50), but sensitive to streptomycin (100). The predominant menaquinone is MK-7. Major cellular fatty acids are $\mathrm{C}_{16: 1} \omega 7 c$, iso- $\mathrm{C}_{15: 0}$, and $\mathrm{C}_{16: 0}$. The DNA G $+\mathrm{C}$ content of the type strain is $48 \mathrm{~mol} \%$ (determined by HPLC).

The type strain, Gsoil $043^{\mathrm{T}}\left(=\mathrm{KCTC} 12589^{\mathrm{T}}=\mathrm{LMG}\right.$ $\left.23409^{\mathrm{T}}\right)$, was isolated from soil of a ginseng field in Pocheon province, South Korea.

\section{Acknowledgements}

This work was supported by the 2006 research program of Rural Development Administration, Republic of Korea. We thank Jean Euzéby for his help with the etymology of the species epithet.

\section{References}

Atlas, R. M. (1993). Handbook of Microbiological Media. Edited by L. C. Parks. Boca Raton, FL: CRC Press.

Buck, J. D. (1982). Nonstaining ( $\mathrm{KOH})$ method for determination of gram reactions of marine bacteria. Appl Environ Microbiol 44, 992-993.
Chaturvedi, P., Reddy, G. S. N. \& Shivaji, S. (2005). Dyadobacter hamtensis sp. nov., from Hamta glacier, located in the Himalayas, India. Int J Syst Evol Microbiol 55, 2113-2117.

Chelius, M. K. \& Triplett, E. W. (2000). Dyadobacter fermentans gen. nov., sp. nov., a novel Gram-negative bacterium isolated from surfacesterilized Zea mays stems. Int J Syst Evol Microbiol 50, 751-758.

Felsenstein, J. (1985). Confidence limits on phylogenies: an approach using the bootstrap. Evolution 39, 783-791.

Fitch, W. M. (1971). Toward defining the course of evolution: minimum change for a specific tree topology. Syst Zool 20, 406-416.

Güde, H. (1980). Occurrence of cytophagas in sewage plants. Appl Environ Microbiol 39, 756-763.

Hall, T. A. (1999). BIOEDIT: a user-friendly biological sequence alignment editor and analysis program for Windows 95/98/NT. Nucleic Acids Symp Ser 41, 95-98.

Hiraishi, A., Ueda, Y., Ishihara, J. \& Mori, T. (1996). Comparative lipoquinone analysis of influent sewage and activated sludge by highperformance liquid chromatography and photodiode array detection. $J$ Gen Appl Microbiol 42, 457-469.

Im, W.-T., Jung, H.-M., Cui, Y.-S., Liu, Q.-M., Zhang, S.-L. \& Lee, S.-T. (2005). Cultivation of the three hundreds of bacterial species from the soil of the ginseng field and mining the novel lineage bacteria. In Proceedings of the International Meeting of the Federation of Korean Microbiological Societies, abstract A035, p. 169. Seoul: Federation of Korean Microbiological Societies.

Kim, M. K., Im, W.-T., Ohta, H., Lee, M. \& Lee, S.-T. (2005). Sphingopyxis granuli sp. nov., a $\beta$-glucosidase-producing bacterium in the family Sphingomonadaceae in $\alpha-4$ subclass of the Proteobacteria. J Microbiol 43, 152-157.

Kimura, M. (1983). The Neutral Theory of Molecular Evolution. Cambridge: Cambridge University Press.

Kouker, G. \& Jaeger, K.-E. (1987). Specific and sensitive plate assay for bacterial lipases. Appl Environ Microbiol 53, 211-213.

Kumar, S., Tamura, K. \& Nei, M. (2004). MEGA3: Integrated software for molecular evolutionary genetics analysis and sequence alignment. Brief Bioinform 5, 150-163.

Mesbah, M., Premachandran, U. \& Whitman, W. B. (1989). Precise measurement of the $\mathrm{G}+\mathrm{C}$ content of deoxyribonucleic acid by highperformance liquid chromatography. Int J Syst Bacteriol 39, 159-167.

Moore, D. D. \& Dowhan, D. (1995). Preparation and analysis of DNA. In Current Protocols in Molecular Biology, pp. 2-11. Edited by Ausubel, F. M., Brent, R., Kingston, R. E., Moore, D. D., Seidman, J. G., Smith, J. A. \& Struhl, K. New York: Wiley.

Reddy, G. S. N. \& Garcia-Pichel, F. (2005). Dyadobacter crusticola sp. nov., from biological soil crusts in the Colorado Plateau, USA, and an emended description of the genus Dyadobacter Chelius and Triplett 2000. Int J Syst Evol Microbiol 55, 1295-1299.

Saitou, N. \& Nei, M. (1987). The neighbor-joining method: a new method for reconstructing phylogenetic trees. Mol Biol Evol 4, 406-425.

Sasser, M. (1990). Identification of bacteria by gas chromatography of cellular fatty acids. MIDI Technical Note 101. Newark, DE: MIDI Inc.

Stackebrandt, E. \& Goebel, B. M. (1994). Taxonomic note: a place for DNA-DNA reassociation and 16S rRNA sequence analysis in the present species definition in bacteriology. Int J Syst Bacteriol 44, 846-849.

Ten, L. N., Im, W.-T., Kim, M.-K., Kang, M.-S. \& Lee, S.-T. (2004). Development of a plate technique for screening of polysaccharidedegrading microorganisms by using a mixture of insoluble chromogenic substrates. J Microbiol Methods 56, 375-382. 
Thompson, J. D., Gibson, T. J., Plewniak, F., Jeanmougin, F. \& Higgins, D. G. (1997). The CLUSTAL_X windows interface: flexible strategies for multiple sequence alignment aided by quality analysis tools. Nucleic Acids Res 25, 4876-4882.

Tschech, A. \& Pfennig, N. (1984). Growth yield increase linked to caffeate reduction in Acetobacterium woodii. Arch Microbiol 137, 163-167.

Weeks, O. B. (1981). Preliminary studies of the pigments of Flavobacterium breve NCTC 11099 and Flavobacterium odoratum NCTC 11036. In The Flavobacterium-Cytophaga Group, pp. 109-114. Edited by H. Reichenbach \& O. B. Weeks. Weinheim: Gesellschaft Für Biotechnologische Forschung.

Widdel, F. \& Bak, F. (1992). Gram-negative mesophilic sulfatereducing bacteria. In The Prokaryotes, 2nd edn, pp. 3352-3378. Edited by A. Balows, H. G. Trüper, M. Dworkin, W. Harder \& K. H. Schleifer. New York: Springer.

Widdel, F., Kohring, G. \& Mayer, F. (1983). Studies on dissimilatory sulfate-reducing bacteria that decompose fatty acids. III. Characterization of the filamentous gliding Desulfonema limicola gen. nov., sp. nov., and Desulfonema magnum sp. nov. Arch Microbiol 134, 286-294. 